\title{
MESIN PENCAMPUR PAKAN BASAH SAPI PERAH UNTUK PETERNAK MENENGAH KE BAWAH
}

\author{
Kuncoro Diharjo \\ Dosen Teknik Mesin Universitas Negeri Sebelas Maret Surakarta \\ Kampus Kentingan Surakarta \\ email : kuncorodiharjo@uns.ac.id
}

\begin{abstract}
ABSTRAKSI
Di lingkungan peternak sapi perah Musuk Boyolali, mesin pencacah pakan sudah ada. Untuk mendukung mekanisasi pengolahan pakan, rekayasa mesin pencampur mutlak diperlukan. Mesin ini diharapkan mampu menghasilkan campuran pakan yang homogen, mempersingkat waktu pencampuran, dan mereduksi biaya operasional pengolahan pakan. Pencampuran pakan yang dilakukan dengan mesin ini adalah pencampuran pakan basah. Manufaktur prototype mesin dilakukan dengan menggunakan mesin-mesin konvensional. Mesin didisain dengan posisi tong vertikal dan disain ruji pengaduk mengadopsi disain ruji blender. Mesin ini digerakkan oleh motor listrik satu fase dengan daya 1 HP. Hasil uji coba mesin menunjukkan bahwa mesin pencampur dapat bekerja dengan baik, sesuai harapan peternak/ KUD. Penggunaan mesin pencampur ini mampu menekan waktu pengolahan pakan menjadi 33,65 \% dibandingkan pengolahan pakan secara manual. Biaya pengolahan pakan pun dapat diturunkan menjadi 62,7\% dibandingkan pengolahan pakan secara manual
\end{abstract}

Kata-kata kunci: pakan basah, mesin pencampur, ruji pengaduk

\section{PENDAHULUAN}

Pada umumnya, setiap penduduk di Kecamatan Musuk Kabupaten Boyolali memelihara 1-3 ekor sapi. Namun, ada juga kalangan peternak menengah yang memelihara lebih dari 10 ekor sapi perah. Peternak masih menggunakan sistem konvensional dalam pengolahan pakannya, yaitu bahan pakan dipotong-potong dengan sabit, dan dicampur secara manual. Akibatnya kualitas pakan tersebut rendah. Ternak sapi perah harus diberi pakan secara teratur, agar produktivitas susunya tak terhenti, bahkan meningkat. Susu segar sebagian dipasarkan secara langsung ke konsumen setelah dimasak dan sisanya dijual ke industri (PT. Sari Husada), melalui KUD Musuk. Pemasaran susu segar di Karesidenan Surakarta cukup menjanjikan, karena banyak pedagang susu segar lesehan di pinggir jalan. Harganya pun lebih murah dibanding susu kemasan. Seiring dengan melonjaknya harga kebutuhan hidup, susu segar ini merupakan minuman bergizi alternatif terbaik bagi masyarakat menengah ke bawah. Hal ini menuntut para peternak untuk meningkatkan kualitas dan kuantitas produk susu segar untuk memenuhi kebutuhan konsumen.

Ketika musim kemarau tiba, para peternak mulai merasa kesulitan dalam penyediaan pakan sehingga dapat menyebabkan turunnya produktifitas susu. Peternak harus berusaha mencari sumber makanan alternatif. Peningkatan pengolahan pakan pun menjadi penting untuk menghasilkan secara baik, agar 
pakan habis tanpa sisa. Pencacahan pakan sudah dapat dilakukan dengan mesin pencacah hasil program Vucer Dikti 2003 (Diharjo dkk, 2003), seperti gambar 1. Pencampuran pakan kering juga sudah dapat dilakukan dengan menggunakan mesin pemcampur dengan posisi tong miring, hasil program vucer 2004 (Kusharjanta dkk, 2004). Namun, proses pencampuran pakan basahnya masih dilakukan secara manual. Oleh karena itu, rekayasa mesin pencampur pakan basah menjadi penting untuk dilakukan. Hal ini menunjang program intensifikasi peternakan, khususnya mekanisasi pengolahan pakan sapi agar dihasilkan kualitas dan kuantitas pakan yang memadai.

Program ini juga ditujukan untuk mengubah budaya peternak dari pengolahan pakan manual menjadi mekanis/ dengan mesin. Program ini ini membantu peternak meningkatkan efisiensi pengolahan pakan dan meningkatkan kualitas pakan, sehingga mampu meningkatkan kuantitas dan kualitas produksi susu sapi perah.

\section{TINJAUAN PUSTAKA}

\section{Kajian Ternak Sapi dan Makanannya}

Payne (1969) menyimpulkan pengaruh iklim pada sapi tercermin pada perilaku merumputnya. Panjangnya waktu merumput siang hari bervariasi tergantung dari tingkat stress sapi terhadap iklim, bangsa dan tipe, kualitas dan kuantitas pasture yang tersedia. Cuthberson (1969) menyatakan bahwa rata-rata efisiensi pengubahan tanaman menjadi protein hewani selama masa produksi susu di daerah tropik hanya $25 \%$.

Berbagai jenis rumput, batang pohon, umbi dan daun merupakan bahan utama makanan ternak sapi. Namun bagi sapi perah perlu diberikan makanan dengan komposisi yang tepat agar produksi susunya lancar (Soeyanto, 1981). Berdasarkan hasil penelitian, berbagai jenis rumput, daun, umbi dan jenis dedak, maka kadar protein dan lemak yang terkandung di dalamnya ditunjukkan pada tabel 1.

Pada zaman dahulu semua makanan ternak terdiri dari tiga sumber, yaitu (1) tanaman selain rumput-rumputan sebagai hasil sampingan dari pengolahan makanan dan ternak, (2) rumput-rumputan alamiah dan (3) yang ditanam. Sekarang ada sumber yang keempat yang mungkin mulai berperan yaitu sintesa dari bahan-bahan yang bukan biologis, seperti urea dari nitrogen atau protein konsentrat dari minyak atau gas alam (Williamson dan Payne, 1993)

\section{Kajian Teknologi}

Salah satu jenis bahan poros yang sering digunakan adalah baja S45C. Poros baja S45C yang menderita kombinasi beban tarik-tekan dinamis akan mengalami kegagalan yang lebih awal dibandingkan dengan beban statis. perancangan komponen mesin harus selalu mempertimbangkan adanya tambahan beban impak (Diharjo, 2000).

Tabel 1. Kadar protein dan lemak bahan makanan sapi (Soeyanto, 1981)

\begin{tabular}{lcccc}
\hline \multicolumn{1}{c}{ Nama Bahan } & \multicolumn{2}{c}{ Kadar Protein(\%) } & \multicolumn{2}{c}{ Kadar Lemak(\%) } \\
& Minimal & Maksimal & Minimal & Maksimal \\
\hline Rumput-rumputan & 6,26 & 11,89 & 0,71 & 2,32 \\
Daun-daunan & 12,50 & 36,80 & 1,25 & 9,94 \\
Umbi-umbian & 0,50 & 2,0 & 0,1 & 0,6 \\
dedak/ ampas & 0,80 & 42,70 & 0,20 & 12,60 \\
\hline
\end{tabular}


Selain itu, kehadiran takik pada komponen mesin akan menimbulkan konsentrasi tegangan. Pada lebar dan tebal plat yang sama, diameter lubang yang semakin besar menyebabkan menurunnya kekuatan yang signifikan. Perilaku ini menunjukkan bahwa semakin besar lubang semakin besar pula konsentrasi tegangannya (Diharjo, 1999).

Menurut Diharjo (2003), salah satu solusi penanganan kekurangan pakan sapi perah di musim kemarau adalah dengan meningkatkan intensifikasi peternakan.
Bagi kalangan peternak menengah ke bawah, rekayasa mesin pencacah pakan sapi dapat mengatasi kekurangan pakan. Dengan mesin ini, berbagai bahan pakan dapat dicacah dengan ukuran kecil-kecil sehingga habis dimakan oleh sapi. Bahan yang biasa diolah dengan mesin ini di musim kemarau antara lain pohon jagung, pohon papaya, pohon singkong, dan ranting-ranting muda. Pengadaan mesin pencacah ini mampu mengatasi kekurangan pakan sapi perah dan sekaligus dapat mempertahankan produksi susu, khususnya di musim kemarau.

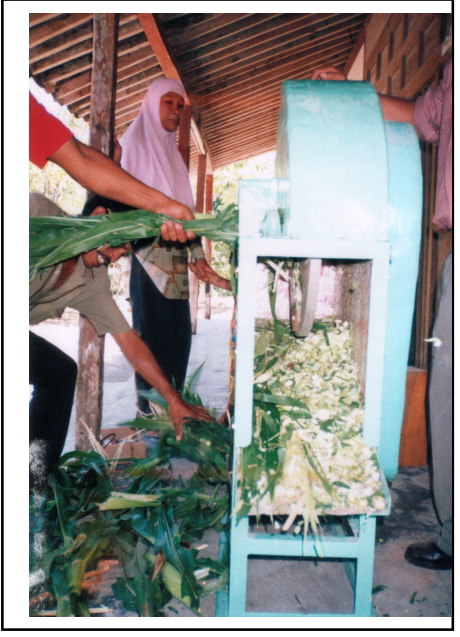

Gambar 1. Mesin pencacah pakan

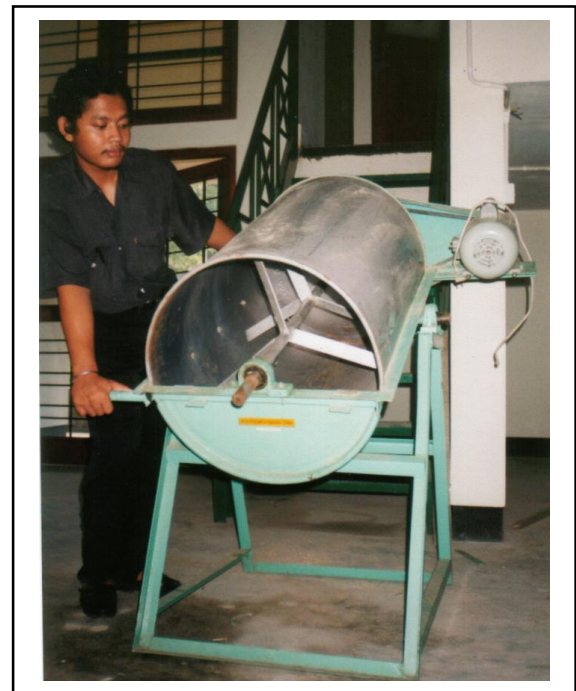

Gambar 2. Mesin pencampur pakan kering (Kusharjanta dkk, 2004) 
Keberlanjutan dari program Vucer 2003 tersebut di atas ditindaklanjuti dengan rekayasa mesin pencampur pakan sapi kering (komboran kering). Ruang pencampur direkayasa dari bahan tong bekas dengan posisi miring, seperti pada gambar 2. Pemanfaatan mesin ini sudah dilakukan di KUD Musuk Boyolali. Mesin pencampur ini dapat bekerja dengan baik untuk campuran pakan yang dicacah kecilkecil. Bahan yang biasa dicampur adalah cacahan pohon jagung, rumput gajah, katul, konsentrat kering, dan bahan tambahan lainnya. Kombinasi penggunaan mesin pencacah dan mesin pencampur ini ini dapat mengatasi adanya permasalahan ketidakhabisan pakan kering sapi perah (Kusharjanta dkk, 2004)

\section{METODE}

Komponen utama mesin ini adalah tong pencampur, ruji pencampur, motor listrik penggerak, system transmisi, dan rangka utama. Pembuatan semua komponen tersebut dapat dikerjakan dengan mesin konvensional. Proses pembuatan dimulai dari disain, rekayasa mesin dan penyempurnannnya, ujicoba mesin, perbaikan disain, pemanfaatan mesin oleh peternak, dan pengembangan disain. Tahapan rekayasa mesin pencampur ini ditunjukkan secara rinci pada gambar 3.

Penyempurnaan disain dilakukan secara kontinyu dengan mengakomodasi ide-ide dari peternak dan bengkel rekayasa. Perubahan disain juga dilakukan selama proses rekayasa. Kelayakan produk mesin juga diujikan secara langsung di lokasi peternakan. Prototype produk disosialisasikan ke Pemda sekaresidenan Surakarta melalui kegiatan seminar nasional di Lembaga Pengabdian masyrakat UNS Surakarta.

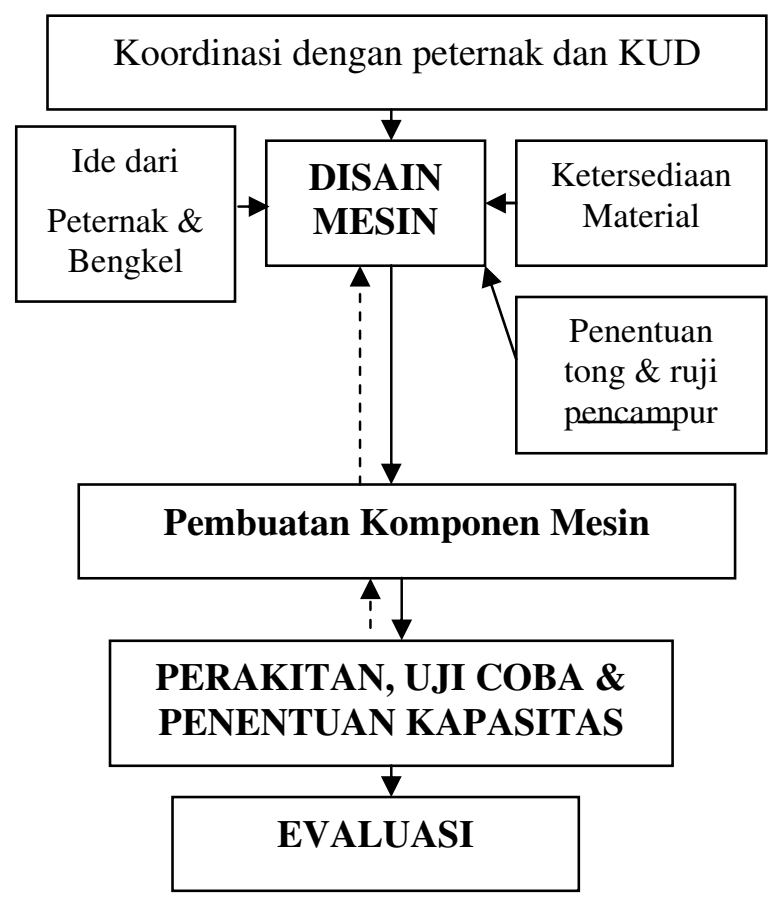

Gambar 3. Diagram alir rekayasa mesin pencacah makanan 
HASIL DAN PEMBAHASAN

Data Hasil Survei dan Spesifikasi Mesin Pencampur

Jumlah sapi yang dipelihara peternak rumah tangga adalah 1-3 ekor, sedangkan peternak menengah umumnya memelihara lebih dari 10 ekor sapi perah. Jumlah peternakan sapi terbesar yaitu di KUD Musuk sebanyak 40 ekor. Pola pemberian pakan sapi setiap harinya terdiri dari komboran, rumput, dan minuman. Komboran basah diberikan pagi dan sore hari, dengan volume 1 ember (sekitar 8 liter). Bahan baku komboran antara lain konsentrat, cacahan rumput, ampas tahu, bungkil, dan air. Pakan kering (rumput, jerami, dan lain-lain) diberikan di sela-sela komboran basah. Pengolahan pakan yang benar-benar memerlukan waktu dan tenaga adalah pengolahan komboran basah. Oleh karena itu, rekayasa mesin pencacah sebelumnya dan mesin pencampur sangat membantu para peternak.

Tabel 2. Spesifikasi mesin pencampur pakan basah.

\begin{tabular}{ll}
\hline \multicolumn{1}{c}{ Spesifikasi } & \multicolumn{1}{c}{$\begin{array}{c}\text { Mesin Pencampur Pakan } \\
\text { Basah }\end{array}$} \\
\hline Jenis Penggerak & Motor listrik 1 fase 1 HP \\
Sistem Transmisi & V-belt tipe A \\
Dimensi Mesin $(\mathrm{cm})$ & $\mathrm{P}=110, \mathrm{~L}=110, \mathrm{~h}=190$ \\
Putaran Ruji Pencampur & $400 \mathrm{rpm}$ \\
Model ruji pencampur & mengadopsi ruji blender \\
Ruang Pencampur & Tong diameter $80 \mathrm{~cm}$ \\
Kapasitas Pencampuran & 50 liter (untuk 6 sapi) \\
Lama Pencampuran & \pm 15 detik \\
Rangka Utama & Baja siku \\
Pengunaan & Campuran pakan basah \\
\hline
\end{tabular}

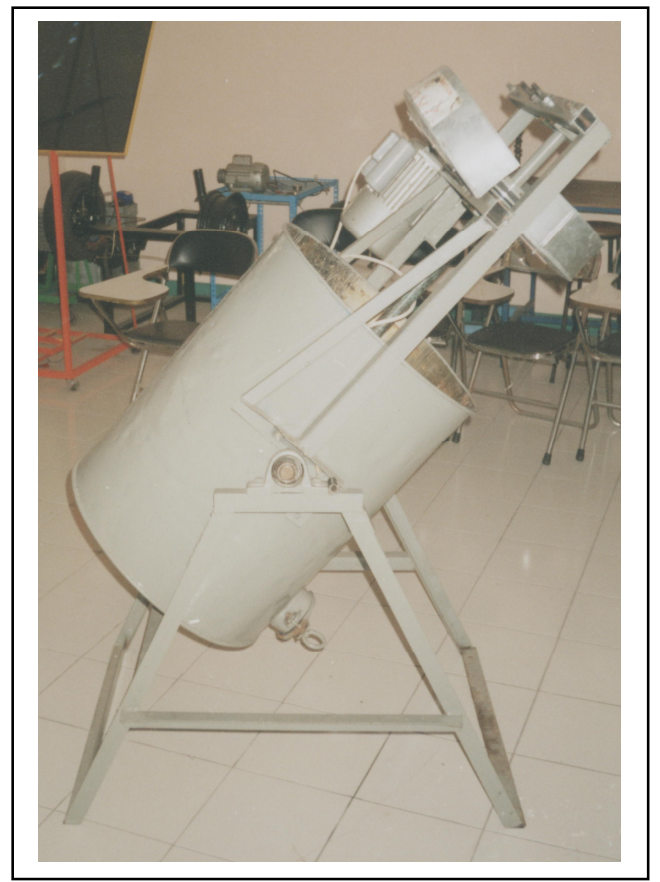

Gambar 4. Prototype mesin pencampur pakan sapi basah (komboran basah) 
Bagi para peternak rumah tangga, kepemilikan mesin disarankan berkelompok sehingga biaya yang ditanggung tiap peternak menjadi sangat murah. Harga mesin ini menjadi terjangkau oleh peternak rumah tangga.

Estimasi nilai ekonomi penggunaan mesin dilakukan bersama oleh Tim KUD Musuk, peternak dan Tim Pengabdi dengan melakukan ujicoba mesin secara langsung. Penggunaan mesin pencampur mampu mereduksi waktu pengolahan pakan sapi basah (komboran) untuk 40 ekor sapi selama satu bulan menjadi hanya 33,65\% dibandingkan dengan pengolahan pakan basah manual. Selama sebulan, pengolahan pakan sapi basah secara manual memerlukan waktu 26 jam, sedangkan dengan mesin ini hanya diperlukan 8,75 jam, seperti tabel 3 .

Hal lain yang menguntungkan penggunaan mesin pencampur ini adalah mampu menurunkan biaya pemberian pakan. Kondisi saat ini, pemberian pakan sapi basah sebanyak 2 kali sehari untuk 40 ekor sapi membutuhkan biaya $\mathrm{Rp}$. 200.000,00 per bulan. Dengan menggunakan mesin pencampur, biaya pemberian pakan tersebut dapat ditekan menjadi Rp. 125.360,94 per bulan. Penggunaan mesin pencampur mampu menekan biaya operasional pemberian pakan sapi 40 ekor menjadi 62,7 \% dibandingkan dengan biaya pemberian pakan sapi secara manual.

Tabel 3. Analisis ekonomi penggunaan mesin.

\begin{tabular}{|c|c|c|}
\hline Kegiatan & $\begin{array}{l}\text { Dikerjakan Dengan Mesin } \\
\text { Pencampur }\end{array}$ & Dikerjakan Manual \\
\hline Daya Motor & $1 \mathrm{Hp}(0,75 \mathrm{~kW})$ & Tidak ada \\
\hline $\begin{array}{l}\text { Volume Pencampuran } \\
\text { untuk sehari (pagi dan sore) }\end{array}$ & $\begin{array}{l}50 \text { liter (untuk } 6 \text { sapi) } \text { x } 7 \text { kali } \\
\text { pengadukan } \times 2 \text { kali proses sehari }\end{array}$ & $\begin{array}{l}25 \text { liter (untuk } 3 \text { sapi) x } 13 \text { kali } \\
\text { pengadukan x } 2 \text { kali proses } \\
\text { sehari }\end{array}$ \\
\hline Waktu Pencampuran & $\begin{array}{l}15 \text { detik untuk tiap pengadukan } \\
\text { (sumber: hasil percobaan) }\end{array}$ & $\begin{array}{l}\text { Minimal } 1 \text { menit untuk tiap } \\
\text { pengadukan }\end{array}$ \\
\hline $\begin{array}{l}\text { Waktu persiapan dan } \\
\text { penyajian untuk tiap } \\
\text { pengadukan }\end{array}$ & $\begin{array}{l}\text { Minimal } 1 \text { menit untuk tiap } \\
\text { pengadukan }\end{array}$ & $\begin{array}{l}\text { Minimal } 1 \text { menit untuk tiap } \\
\text { pengadukan }\end{array}$ \\
\hline $\begin{array}{l}\text { Biaya listrik per bulan }(30 \\
\text { hari) }\end{array}$ & $\begin{array}{l}0,75 \times 15 / 3600 \times \text { Rp. } 275,00 \times 7 \times \\
2 \times 30=\text { Rp. } 360,94\end{array}$ & Tidak ada \\
\hline $\begin{array}{l}\text { Biaya tenaga kerja per } \\
\text { bulan }\end{array}$ & $\begin{array}{l}\text { Rp. } 100.000 \text { (untuk penyiapan } \& \\
\text { penyajian) + Rp. } 25.000 \text { (untuk } \\
\text { pengoperasian mesin) }=\text { Rp. } \\
125.000,00\end{array}$ & $\begin{array}{l}\text { Rp. } 200.000,00 \\
\text { (sumber: kesepakatan kepala } \\
\text { KUD dengan pekerja) }\end{array}$ \\
\hline $\begin{array}{l}\text { Waktu pemberian pakan } \\
\text { per bulan }\end{array}$ & $\begin{array}{l}1 \text { menit } 15 \text { detik x } 7 \text { pengadukan } \\
\text { x } 2 \text { kali } x 30 \text { hari }=8,75 \text { jam }\end{array}$ & $\begin{array}{l}2 \text { menit } \times 13 \text { pengadukan } \times 2 \\
\text { kali } \times 30 \text { hari }=26 \text { jam }\end{array}$ \\
\hline Prosentase waktu & $33,65 \%$ & $100 \%$ \\
\hline $\begin{array}{l}\text { Biaya pemberian pakan } \\
\text { basah per bulan }\end{array}$ & Rp. 125.360,94 & Rp. $200.000,00$ \\
\hline Prosentase Biaya & $62,7 \%$ & $100 \%$ \\
\hline
\end{tabular}

Keterangan :

1. Bahan Baku : Konsentrat kering, Ampas tahu, cacahan rumput dan air.

2. Biaya listrik per KWH untuk daya $900 \mathrm{~W}$ adalah Rp. 275,00.

3. Perhitungan di atas berlaku untuk 40 ekor sapi di kandang percontohan KUD Musuk 
Dengan mesin ini, pencampuran pakan menjadi lebih homogen sehingga menghasilkan kualitas pakan yang lebih baik dan sekaligus meningkatkan produksi susu. Kemudahan dalam pengolahan pakan yang didukung oleh ketersediaan mesin pencacah dan pencampur diharapkan mampu mengeliminasi istilah "sapi mangan sapi" di musim kemarau. Pemanfaatan tong bekas sebagai ruang pencampur merupakan solusi teknologi terhadap banyaknya limbah tong bekas. Dengan menggunakan mesin-mesin manual, bengkel rekayasa mesin sederehana pun dapat memproduksi ulang mesin tersebut. Dengan terjalinnya kerjasama antara peternak, bengkel dan Tim Pengabdi maka penggandaan mesin ini dapat dilakukan kembali. Hal ini akan mampu meningkatkan pendapatan bengkel dan peternak, yang sekaligus mendukung peningkatan pendapatan perkapita daerah.

Mesin ini dapat dioperasikan secara sederhana, yaitu dengan memasukan bahan-bahan pakan yang dicampur dan dilanjutkan dengan menghidupkan mesin. Hal yang harus diperhatikan adalah kapasitas mesin maksimum dibatasi 50 liter. Waktu pencampuran hanya selama 15 detik. Jika kurang homogen maka waktu pencampuran dapat ditambah. Penuangan hasil campuran dilakukan dengan membuka saluran pengeluaran di bagian bawah. Pencampuran ini dapat dilakukan secara berulang-ulang. Setelah mesin dipakai, maka bagian dalam tong pencampur harus dibersihkan, yaitu dengan menyiramkan air ke dalam tong pencampur.

\section{KESIMPULAN}

Dari pembahasan tersebut di atas maka dapat disimpulkan sebagai berikut:

1. Mesin pencampur pakan sapi yang sangat berguna untuk membantu pengolahan pakan sapi bagi peternak adalah mesin pencampur pakan basah (komboran).

2. Penggunaan mesin pencampur pakan basah ini mampu menekan waktu pengolahan pakan sapi menjadi 33,65 $\%$ dibandingkan pengolahan pakan secara manual.

3. Biaya pengolahan pakan sapi basah dengan mesin turun menjadi 62,7 \% dibandingkan pengolahan pakan basah secara manual.

\section{PERSANTUNAN}

Kami mengucapkan terima kasih kepada Dinas P \& K Jawa Tengah yang telah memfasilitasi Program Pengabdian Masyarakat ini melalui dana Proyek Teknologi Tepat Guna (TTG). Ucapan terima kasih yang tulus juga kami sampaikan kepada Wijaya S.T., Haryanto S.Pd., Supono, dan para peternak yang telah mensupport pelaksanaan kegiatan rekayasa mesin pencampur ini

\section{DAFTAR PUSTAKA}

Cuthberson, S. D. P., 1969, Nutrition of Animal of Agricultural Importance, Part 2, Int. Encyc. Food Nutrit., Vol. 17, Pergamon, Oxford.

Diharjo, K., Kusharjanta B. dan Haryanto, 2003. Rancang Bangun Mesin Pencacah Makanan

Ternak sapi Bagi kalangan Peternak menengah Ke Bawah, Vucer Dikti Jakarta. 
Diharjo, K., 2000, Karakteristik Lelah Baja Poros S45C Bertakik V Akibat Kombinasi Beban Amplitudo Konst. Dan Beban Tiba-tiba, Thesis, UGM, Yogyakarta.

Diharjo, K., 1999, Studi Verifikasi Stress Concentration Factor Pada Plat Baja ST 37 Berlubang", Penelt. DIK, FT-UNS, Surakarta.

Kusharjanta B, Diharjo K, dan Haryanto, 2004, Rekayasa Mesin Pencampur Makanan Ternak (Komboran Kering) Sapi Dengan Memanfaatkan Tong Bekas Untuk Kalangan Peternak Menengah Ke Bawah, Vucer, Dikti, Jakarta.

Payne, W. J. A., 1969, Problem of the Nutrition of Ruminants in the Tropics, in the Cuthberson, Sir. D. P. (ed.), "Nutrition of Animal of Agricultural Importance", Part 2, Int. Encyc. Food Nutrit., Vol. 17, Pergamon, Oxford.

Soeyanto, P., 1981, Intensifikasi Peternakan, Cetakan I, Penerbit Balai Aksara-Penerbit Yudhistira, Jakarta. 